\title{
Scientific Research on Remains of the Late-Bronze-Age Copper Production in the Alps
}

\author{
G. Sperl*
}

* Univ.Prof. Dr.phil.Dr.mont.Dipl.-Ing.; Lecturer on Historical Materials at the Universities of Leoben, Innsbruck and Vienna: researcher at the Erich-Schmid Institut für Materialwissenschaft der Österreichischen Akademie der Wissenschaften, Leoben. Now since 2002: Institut für Historische Werkstoffe (IHW-EFDZ), Mareckkai 46, A-8700 Leoben (Austria):

History and situation

For more than seventy years now archeologists have been researching very sophisticated copper smelting in the Alps during the late Bronze-Age (1200-800 $\mathrm{BC}$ )[1]. From the region of lower Austria (Schneeberg-Rax) across northern Styria (Radmer, Eisenerz, Johnsbach, Paltental) and continued in the south of Salzburg (Mühlbach) and eastern Tyrol (Jochberg-Kitzbühel, ) with some traces in the Inn-valley, the northern prehistoric production zone ends in Switzerland (Savognin-Oberhalbstein, GR). In the south late bronze age copper-smelting is researched near Trento (Val Sugana) and some traces are found in the north near Bozen/Bolzano (Margreid, Sarntal) and also in Eastern Tyrol (Matrei); other smelting sites are hoped to be found in future in the southern "Grauwackenzone" in Carinthia [2].

The structure of the smelting sites and the remains of the smelting process are very homogeneous in the whole area, $700 \mathrm{~km}$ wide,: Stone-built twin-furnaces situated on a slope near flowing water with an approx. $40 \mathrm{~cm}$ wide square shape inside (FIG.1), and an apparently open tapping-wall; on the upper part near the deposits for ores and fuel (charcoal), was the clay-lined roasting bead: $1 \mathrm{~m}$ wide and 6 to 20 meters long; below the furnaces (often multiple-twins) the slag-pit, which contains several types of slags (blocks, sand, crystalline, glassy etc.). Very typical in this period was the smelting of copper from chalcopyrite $\left(\mathrm{CuFeS}_{2}\right)$, so that the removal of the sulfur by roasting and of the iron by slagging was state-ofthe-art. The metallurgical method did not really change in the Alps until the arrival of modern copper smelting in about 1820 . 


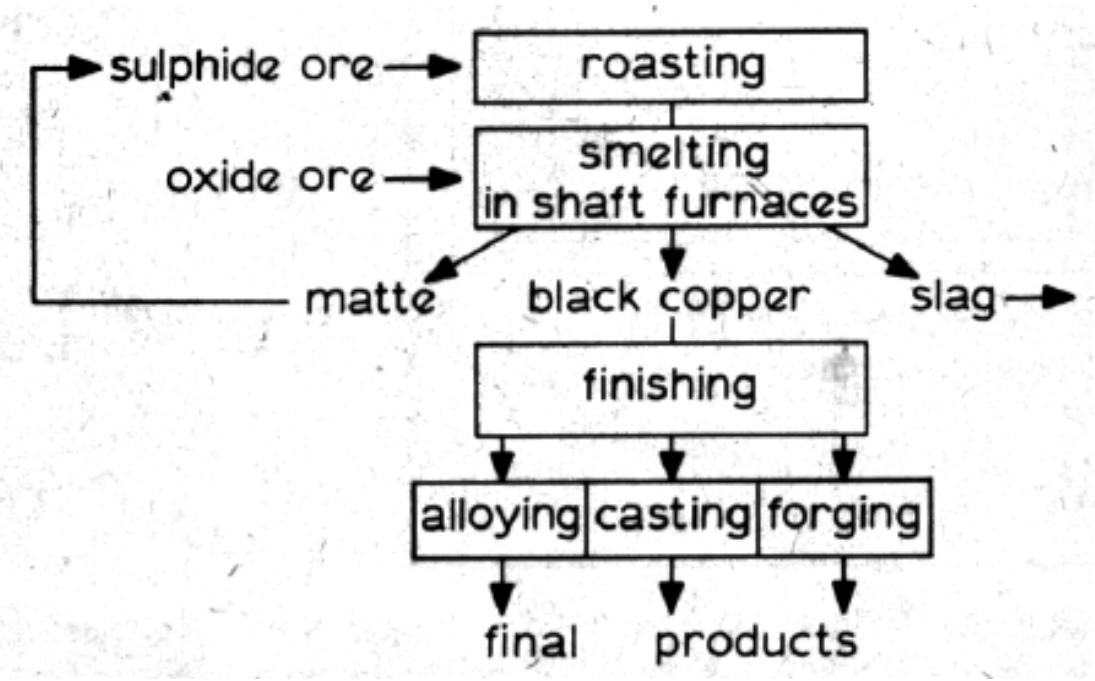

Fig.1: The minimum-process of prehistoric copper smelting in the Alps [5]

Some research has been done on the slags, metallic findings near the furnaces (ingots, speiss) and the bun-ingots found in the Alpine area near there. Through metallographic research the smelting condition can be found and the type of ore used can be characterized $[3,4]$. This is also important for provenancing bronze objects of that period for finding trade routes and commercial relations [5]. The quantity of slags and the dateof the use of the metallurgical equipment, as it can be found by archaeological research, gives some information on the economic and social background of that activity [6].

\section{References}

[1] C.Eibner, Zum Stammbaum einer urzeitichen Kupfererzaufbereitung, in: Berg- und Hüttenmännische Monatshefte, Leoben, 124 (1979), 157-161

[2] ] C.Eibner, H.Preßlinger, G. Sperl, G.Walach Kupfererzverhüttung in Österreich vor 3000 Jahren; in: Kalender für Berg, Hütte und Energie 1982, S.121-127 [3] ] G. Sperl, Metallographic examination of Bronze Age copper; in: Metals Technology, Mai 1980, S.212-217

[4] ] G. Sperl, Eisen im alten Kupfer; in: Freiberger Forschungshefte, B 217 Metallurgie und Werkstofftechnik - Nichteisenmetallurgie, 1980, S.17-25

[5] ] G. Sperl, Metallurgische Unterscheidungskriterien metallischer Funde der Kupfer- und Bronzezeit Europas, in: Fortschritte in der Metallographie, Praktische Metallographie, Sonderband 4, Riederer Verlag Stuttgart 1975, S.3 26

[6] G. Sperl, Metallurgie des urgeschichtlichen Kupferwesens im Alpenraum; in: BHM 133 (1988), H.11, S.495-498 